\title{
RP- HPLC and TLC- densitometric methods for determination of oxfendazole in the presence of its alkali -induced degradation product
}

\begin{abstract}
Accurate, selective, and sensitive reversed phase high performance liquid chromatography (RP-HPLC) and thin-layer chromatography (TLC) - densitometry methods have been developed and validated for determination of oxfendazole in the presence of its alkaliinduced degradation product. The developed RP-HPLC method was based on the separation of the two components using $0.05 \mathrm{M} \mathrm{KH}_{2} \mathrm{PO}_{4}$ (adjusted to $\mathrm{pH}=5$ ), methanol and actonitrile (50:30:20, by volume) as a mobile phase in isocratic elution mode on BDS Hypersil $\mathrm{C}_{18}$ column at a flow rate of $1 \mathrm{~mL} \mathrm{~min}^{-1}$ and ultraviolet (UV) detection at $225 \mathrm{~nm}$. The components were well resolved from each other with significantly different $R_{t}$ values of 7.3 and $4.05 \mathrm{~min}$ for oxfendazole and its alkali-induced degradation product, respectively. The method was applied in the range of $\left(3-15 \mu \mathrm{gLL}^{-1}\right)$. On the other hand, TLC- densitometric method depends on the separation and quantitation of oxfendazole and its alkali-induced degradation product on TLC silica gel 60 F254 plates, using chloroformmethanol and glacial acetic acid (90:8:2, by volume) as the developing system followed by densitometric measurement at $292 \mathrm{~nm}$. The studied components were well resolved from each other with significantly different $R_{\mathrm{f}}$ values of 0.75 and 0.2 for oxfendazole and its degradation product, respectively. The method was applied in the range of $(0.5-6 \mu \mathrm{g} /$ spot). The developed methods were validated according to the International Conference on Harmonization (ICH) guidelines demonstrating good accuracy and precision. The results were statistically compared with those obtained by the reported method, and no significant difference was found.
\end{abstract}

Keywords: oxfendazole, oxfendazole degradation product, RP-HPLC and TLCdensitometry
Volume 7 Issue 2 - 2018

\section{Fathy M Salama, Khalid AM Attia, Ahmed A Mohamad, Ragab A Said, Ahmed W Madkour Department of Pharmaceutical Analytical Chemistry,Al-Azhar University, Egypt}

Correspondence: Ahmed W Madkour, Assistant lecturer of Analytical Chemistry, Department of Pharmaceutical Analytical Chemistry, Faculty of Pharmacy, Al-Azhar University, Nasr City, Cairo,Egypt,Email ahmedmadkour8@yahoo.com

Received: February 19, 2018| Published: March 19, 2018

\section{Introduction}

Oxfendazole chemically known as: [5-(Phenylsulfinyl)- $1 H$ benzimidazol-2-yl] carbamic acid methyl ester ${ }^{1}$ Figure 1. It is a benzimidazole carbamate anthelmintic used in veterinary medicine. ${ }^{2}$ Different analytical techniques were applied for quantitative estimation of oxfendazole including potentiometric titration, ${ }^{3,4}$ radio immunoassay, ${ }^{5}$ spectrophotometric methods ${ }^{6}$ and HPLC methods even alone or in presence of other compounds. ${ }^{7-17}$ Oxfendazole is an amide group containing compound that made it highly sensitive to hydrolytic degradation in basic conditions with the production of the degradation product 2-amino-5-Phenylsulfinyl benzimidazole. There is no stability indicating analytical methods were reported for determination of oxfendazole in presence of its degradation product. The aim of this work is to develop and validate simple, sensitive and selective chromatographic methods for the determination of oxfendazole in presence of its alkali-induced degradation product (2-amino-5-Phenylsulfinyl benzimidazole) without preliminary separation. The proposed methods were found to be fast and simple and can be used for its routine analysis in quality control laboratories.

\section{Experimental}

\section{Instruments}

a. HPLC, LDC Analytical (Milton Roy, USA), equipped with Diode-array UV-visible detector and auto sampler injector, using BDS Hypersil $\mathrm{C}_{18}$ column $(4.6 \times 250 \mathrm{~mm})$, particle size $(5 \mu \mathrm{m})$. The chromatographic analysis was carried out using (EZ Chrom Elit) data analysis program.

b. Camag Linomat autosampler (Muttenzl, Switzerland), a Camag microsyringe $(100 \mu \mathrm{L})$ and a Camag 35/N/30319 TLC scanner with win CATS software; an ultraviolet (UV) lamp with a short wavelength at $254 \mathrm{~nm}$ (Desaga, Wiesloch, Germany).

c. Aluminum TLC plates precoated with silica gel 60 GF254 $(20 \times 20 \mathrm{~cm}),($ Merck, Darmstadt, Germany).

d. Chromatographic tank $(25 \times 25 \times 9 \mathrm{~cm})$.

e. Hot plate (Torrey pines Scientific, USA).

f. Jenway, $3510 \mathrm{pH}$ meter (Jenway, USA).

g. Rotatory evaporator (Scilogex-RE 100-pro, USA).

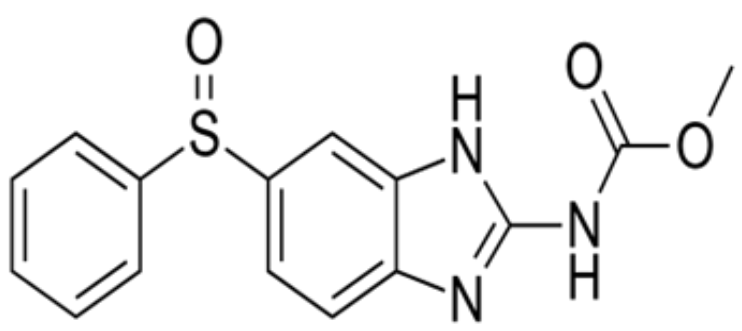

Figure I Chemical structure of oxfendazole. 


\section{Materials and reagents}

\section{Pure standard}

Standard oxfendazole powder was kindly supplied by Unipharma Co. for pharmaceutical industries, Al Obour city, Cairo, Egypt. (B. NO.60414005).

\section{Pharmaceutical preparation}

Unifendazole $^{\circledR}$ suspension, the product of Unipharma Co. for pharmaceutical industries, AlObour city, Cairo, Egypt. (B.NO.390215), which labeled to contain $22.5 \% \mathrm{w} / \mathrm{v}$ oxfendazole.

\section{Reagents and solvents}

a. Hydrochloric acid, (El-Nasr Co., Egypt), prepared as $0.1 \mathrm{M}$ methanolic solution and $1 \mathrm{M}$ aqueous solution.

b. Sodium hydroxide, (El-Nasr Co., Egypt), prepared as $1 \mathrm{M}$ aqueous solution.

c. Methanol, acetonitrile and chloroform, all of HPLC grade, (Sigma-Aldrich, Germany).

d. Glacial acetic acid and $O$-phosphoric acid.

a. $0.05 \mathrm{M}$ phosphate buffer solution, prepared by dissolving $3.4 \mathrm{gm}$ of potassium dihydrogen phosphate $\left(\mathrm{KH}_{2} \mathrm{PO}_{4}\right)$ in $500 \mathrm{~mL}$ distilled water and the solution adjusted to $(\mathrm{pH}=5)$ using $o$ - phosphoric acid.

\section{Degraded sample}

One gram of oxfendazole was dissolved in $25 \mathrm{~mL} 0.1 \mathrm{M}$ methanolic hydrochloric acid, and then transferred into $250 \mathrm{~mL}$ conical flask, then $50 \mathrm{~mL}$ of $1 \mathrm{M} \mathrm{NaOH}$ solution was added. The flask was heated to boiling under reflux for $1 \mathrm{hr}$, cooled and neutralized with $1 \mathrm{M}$ $\mathrm{HCl}$. Subsequently, the solution was dried under vacuum then the degradation product was extracted with methanol and re-crystallized after evaporating methanol.

\section{Standard solutions}

a. Stock standard solution of oxfendazole $\left(1 \mathrm{mg} \mathrm{mL}^{-1}\right)$ was prepared by dissolving $0.1 \mathrm{~g}$ of oxfendazole in $10 \mathrm{~mL} 0.1 \mathrm{M}$ methanolic hydrochloric acid and complete to $100 \mathrm{~mL}$ with methanol.

b. Working solution of oxfendazole $\left(100 \mu \mathrm{g} \mathrm{mL} \mathrm{mL}^{-1}\right): 10 \mathrm{~mL}$ of oxfendazole accurately transferred from its stock standard solution into $100 \mathrm{~mL}$ volumetric flask, then the volume was completed to the mark with methanol.

c. Stock standard solution of oxfendazole degradation product $\left(1 \mathrm{mg} \mathrm{mL}^{-1}\right)$ was prepared by dissolving $0.1 \mathrm{~g}$ of (2-amino-5Phenylsulfinyl benzimidazole) in $50 \mathrm{~mL}$ methanol and complete to $100 \mathrm{~mL}$ with the same solvent.

d. Working solution of oxfendazole degradation product $(100 \mu \mathrm{g}$ $\left.\mathrm{mL}^{-1}\right): 10 \mathrm{~mL}$ of oxfendazole degradation product accurately transferred from its stock standard solution into $100 \mathrm{~mL}$ volumetric flask, then the volume was completed to the mark with methanol.

\section{Procedures}

\section{Construction of calibration curves}

RP-HPLC method: Aliquots of oxfendazole equivalent to (30-
$150 \mu \mathrm{g})$, were accurately transferred from its respective working standard solution $\left(100 \mu \mathrm{g} \mathrm{mL}^{-1}\right)$ into a set of $10 \mathrm{~mL}$ volumetric flasks and the volume was then completed to the mark with the mobile phase [potassium dihydrogen phosphate $(\mathrm{pH}=5)$ : methanol: acetonitrile] (50:30:20, by volume). A $20 \mu \mathrm{L}$ aliquot of each solution was injected into a BDS Hypersil $\mathrm{C}_{18}$ column $(4.6 \times 250 \mathrm{~mm})$, particle size $(5 \mu \mathrm{m})$, using the mobile phase, at flow rate $1.0 \mathrm{~mL} \mathrm{~min}^{-1}$ and UV detection at $225 \mathrm{~nm}$. Calibration curve was constructed by plotting the peak area against the corresponding concentrations of oxfendazole.

TLC-densitometry method: Accurately measured aliquots of oxfendazole stock standard solution $\left(1 \mathrm{mg} \mathrm{mL}^{-1}\right)$ were spotted onto TLC plate using Camag Linomat auto sampler with micro syringe $(100 \mu \mathrm{L})$. The plate was then developed by the ascending technique using chloroform: methanol: acetic acid (90:8:2, by volume) as a mobile phase. The plate was then removed and air-dried. The chromatogram was scanned at $292 \mathrm{~nm}$. Calibration curve representing the relationship between integrated peak area and the corresponding concentrations of oxfendazole was plotted.

\section{Application to laboratory prepared mixtures}

Aliquots of oxfendazole and its degradation product were mixed to prepare different mixtures containing different ratios of both. The procedures mentioned under construction of calibration curves were followed and the concentrations of oxfendazole were calculated.

\section{Application to pharmaceutical formulation}

Volume of Unifendazole ${ }^{\circledR}$ suspension (22.5 w/v oxfendazole) equivalent to $250 \mathrm{mg}$ oxfendazole was accurately taken and dissolved in $10 \mathrm{~mL} 0.1 \mathrm{M}$ methanolic hydrochloric acid in $250 \mathrm{~mL}$ flask then complete to volume with methanol, shacked, and then filtered to obtain a solution labeled to contain $\left(1 \mathrm{mg} \mathrm{mL}^{-1}\right)$ of oxfendazole. $10 \mathrm{~mL}$ of the filtrate were accurately transferred into $100 \mathrm{~mL}$ volumetric flask then complete to volume with methanol to obtain a solution labeled to contain $\left(100 \mu \mathrm{g} \mathrm{mL}^{-1}\right)$ of oxfendazole. The solution was analyzed using the procedures described previously.

\section{Results and discussion}

\section{Degradation of oxfendazole}

It is found that complete alkaline degradation of oxfendazole was obtained after refluxing the drug with $1 \mathrm{M}$ sodium hydroxide at $100^{\circ} \mathrm{C}$ for $1 \mathrm{hr}$, and the degradation was confirmed by TLC method using chloroform: methanol: acetic acid ( $90: 8: 2$, by volume) as a developing system, where a suggested degradation pathway is shown as follows:

Identification of the degradation product: Infra red (IR) spectrum of the degradation product showed abroad peak at $3404 \mathrm{~cm}^{-1}$ which may be assigned to the primary amine group, also disappearance of the peaks at $2741 \mathrm{~cm}^{-1}$ of the methyl group and at $1724 \mathrm{~cm}^{-1}$ of the carbonyl group, (Figure 2 \& Figure 3). Mass spectrometry showed that the compound has a molar mass of 256.96 indicating the presence of the degradation product, (Figure $4 \&$ Figure 5).

In conclusion, all the above evidences indicate that the degradation product could be 2-amino-5-Phenylsulfinyl benzimidazole, (Scheme 1). The suggested chromatographic system for the HPLC method allows complete base line separation at reasonable time. ${ }^{18}$ Planar chromatography with precise application of the samples and computer controlled evaluation and quantification of the developed chromatograms has been considered to be a reliable technique for purity control and for quantitative drug testing. ${ }^{19}$ 
Chromatographic conditions: Several trials were applied to develop the optimum chromatographic conditions for the sufficient separation of oxfendazole and its degradation product.

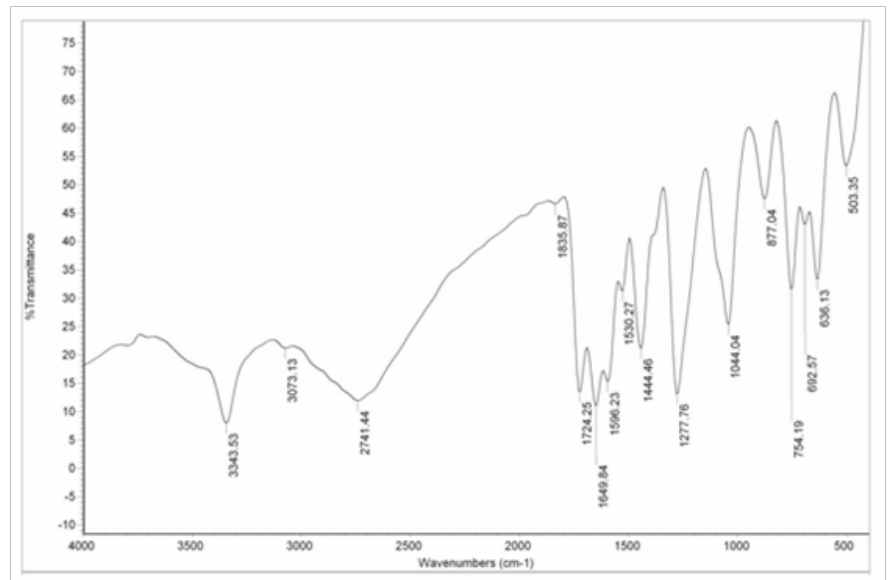

Figure 2 IR spectrum of intact oxfendazole on $\mathrm{KBr}$ disc.

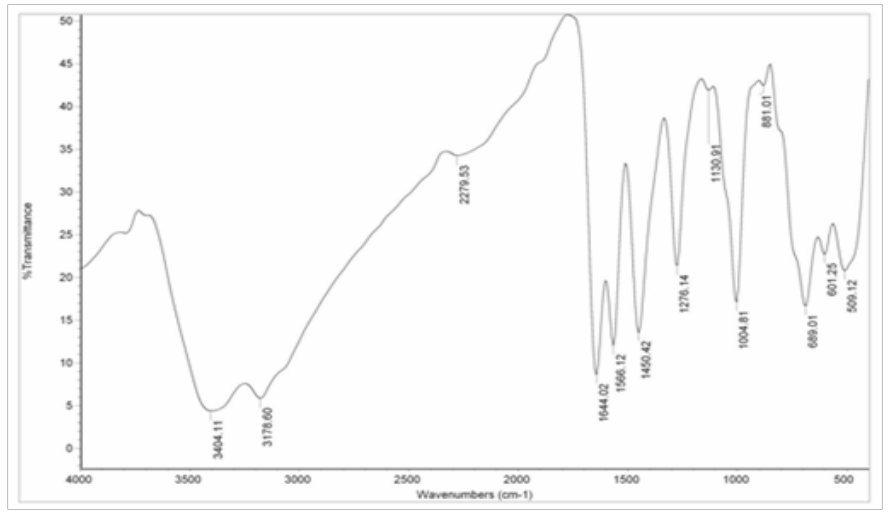

Figure 3 IR spectrum of oxfendazole degradation product on $\mathrm{KBr}$ disc.

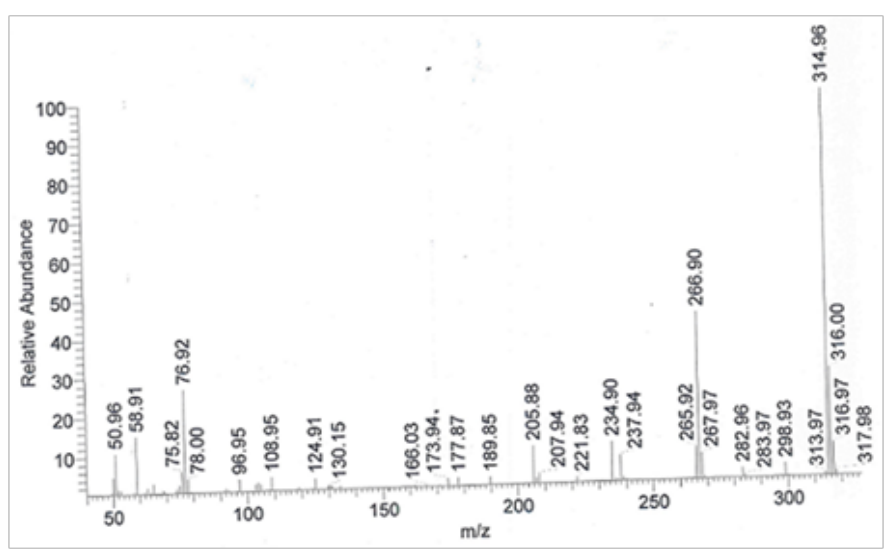

Figure 4 Mass spectrum of intact oxfendazole.

HPLC method was applied to separate oxfendazole and its degradation product, therefore several trials have been undertaken to reach the optimum stationary/mobile phases matching. Good chromatographic separation of the two components in their mixtures could be achieved by using BDS Hypersil $\mathrm{C}_{18}$ column $(4.6 \times 250 \mathrm{~mm})$, particle size $(5 \mu \mathrm{m})$, with a mobile phase consisting of (potassium dihydrogen phosphate $(\mathrm{pH}$ 5): methanol: acetonitrile (50:30:20,

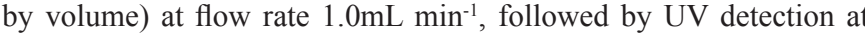
$225 \mathrm{~nm}$, (Figure 6). The results of the TLC system were satisfactory when using chloroform: methanol: acetic acid (90:8:2, by volume) as the developing system. $R_{\mathrm{f}}$ values were found to be 0.75 and 0.20 for oxfendazole and its degradation product, respectively as shown in (Figures 7-9). This separation allows the determination of oxfendazole at $292 \mathrm{~nm}$ without any interference from its degradation product.

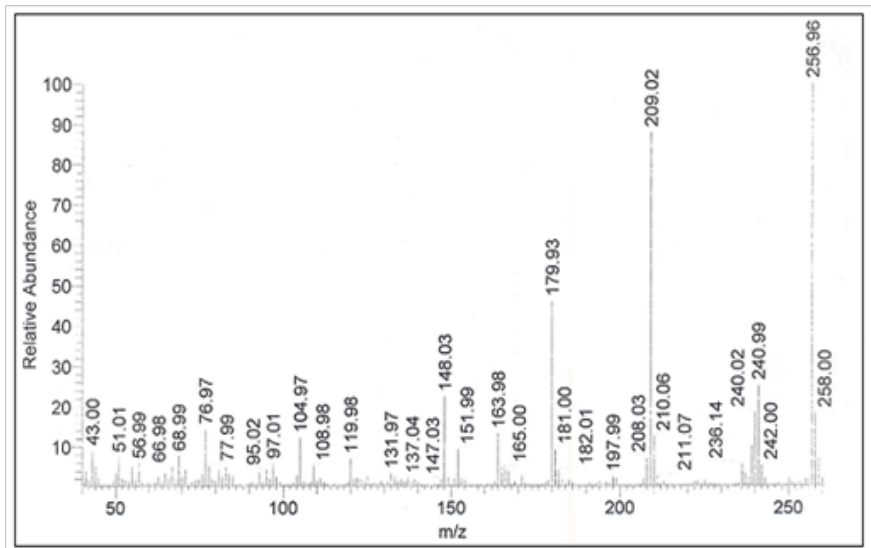

Figure 5 Mass spectrum of intact oxfendazole degradation product.

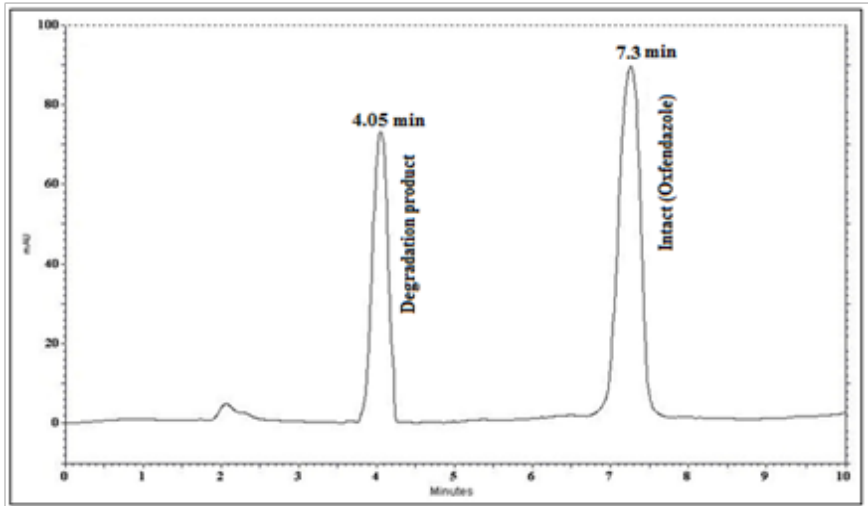

Figure $6 \mathrm{HPLC}$ chromatogram of mixture of intact oxfendazole $(10 \mu \mathrm{g} \mathrm{mL}-1)$ and its degradation product $(10 \mu \mathrm{g} \mathrm{mL})$

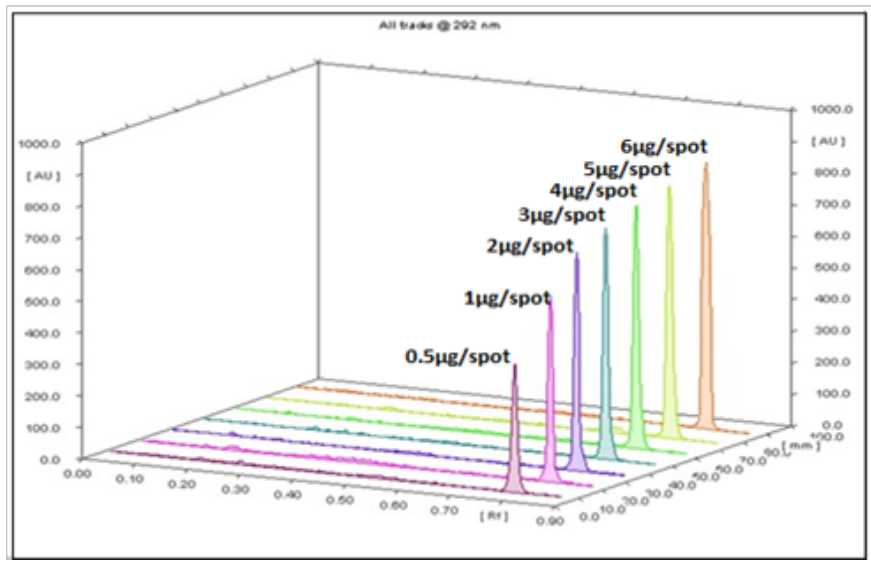

Figure 7 TLC- densitometric chromatogram of oxfendazole (0.5-6 $\mathrm{\mu g} / \mathrm{spot})$ at $292 \mathrm{~nm}$. 


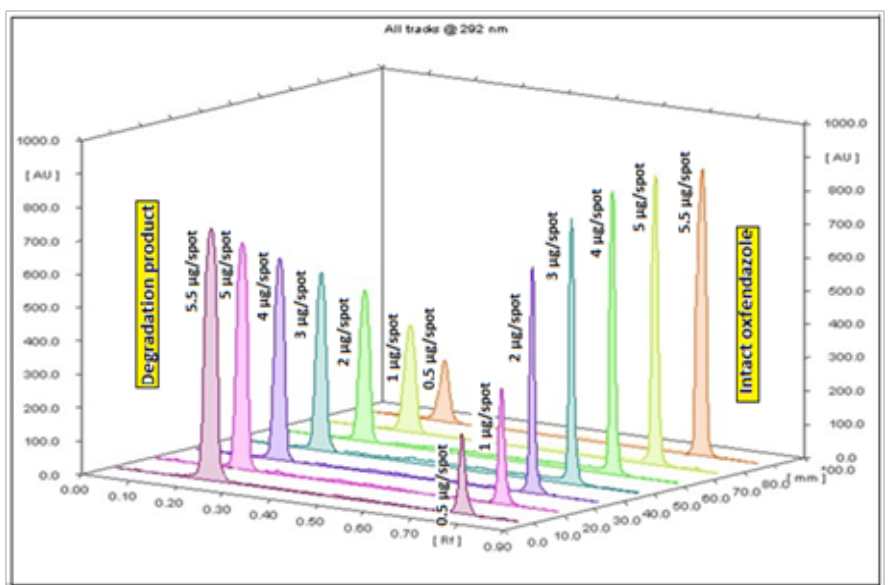

Figure 8 3D TLC- densitometric chromatogram of oxfendazole (0.5-5.5 $\mu \mathrm{g} /$

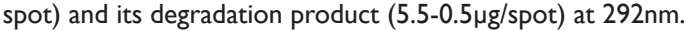

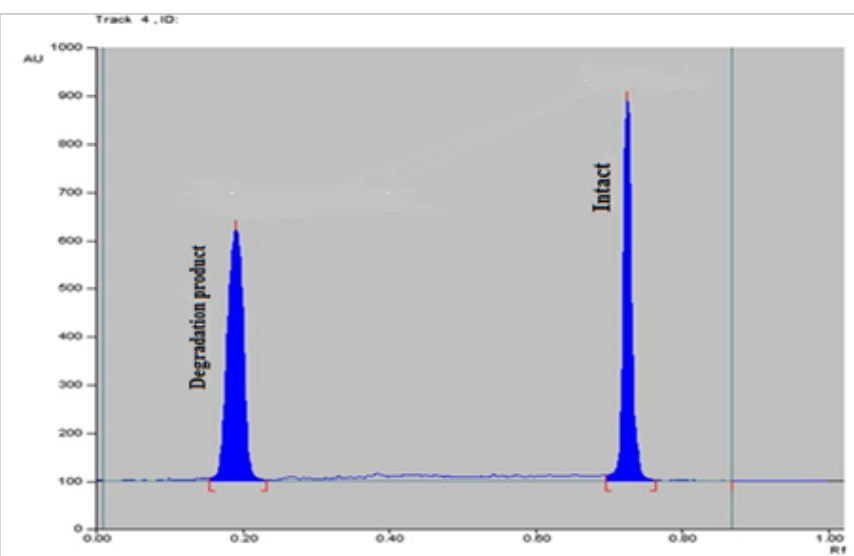

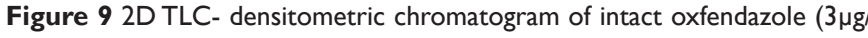

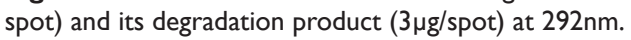

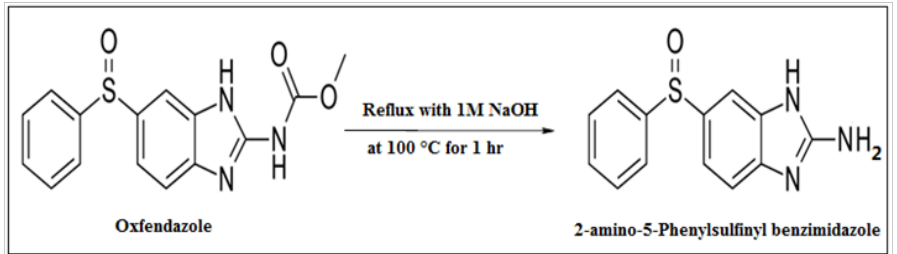

Scheme I Suggested degradation pathway of oxfendazole.

Methods validation: Validations of the proposed methods were assessed as per the ICH guidelines ${ }^{20}$ of accuracy, precision, repeatability, interday precision, linearity.

Linearity and range: Calibration graphs were constructed by plotting the area under peak versus drug concentrations. The regression plot was found to be linear over the range of $\left(3-15 \mu \mathrm{g} \mathrm{mL}^{-1}\right)$ for RP-HPLC method and over the range of $(0.5-6 \mu \mathrm{g} / \mathrm{spot})$ for TLC-densitometric method. The linear regression equations for the graphs were:

$y=139699 x-2848.1$ $\left(r^{2}=0.9998\right)$, for RP-HPLC method.

$y=1188.4 x+4641.8$ densitometric method.
Where $\boldsymbol{y}$ is the area under peak values, $\boldsymbol{x}$ is the drug concentration and $\boldsymbol{r}^{2}$ is the determination coefficient. Linearity range, regression equation, intercept, slope and determination coefficient for the calibration data were presented in Table 1.

Limits of detection and quantitation: The limits of detection (LOD) and the limits of quantitation (LOQ) were calculated according to ICH guidelines from the following equations:

\section{$\mathrm{LOD}=3.3 \sigma / \mathrm{S} \mathrm{LOQ}=10 \sigma / \mathrm{S}$}

Where $\sigma$ is the standard deviation of y-intercepts of regression lines and $\mathrm{S}$ is the slope of the calibration curve. LOD and LOQ values were mentioned in Table 1.

Table 1 Assay validation sheet of the proposed methods

\begin{tabular}{lll}
\hline Parameter & $\begin{array}{l}\text { RP-HPLC } \\
\text { method }\end{array}$ & $\begin{array}{l}\text { TLC-densitometric } \\
\text { method }\end{array}$ \\
\hline $\begin{array}{l}\text { Accuracy (mean } \pm \text { RSD) } \\
\text { Precision }\end{array}$ & $100.25 \pm 0.447$ & $100.10 \pm 0.385$ \\
$\begin{array}{l}\text { Repeatability (RSD) } \\
\text { Intermediate precision }\end{array}$ & 0.3 & 0.48 \\
$\begin{array}{l}\text { (RSD) } \\
\text { Wavelength }\end{array}$ & 0.307 & 0.477 \\
Linearity range & $225 \mathrm{~nm}$ & $292 \mathrm{~nm}$ \\
Slope & $\left(3-15 \mu \mathrm{gL}^{-1}\right)$ & $(0.5-6 \mu \mathrm{g} / \mathrm{spot})$ \\
$\begin{array}{l}\text { Intercept } \\
\text { Cofficient of } \\
\text { determination }\left(\mathrm{r}^{2}\right)\end{array}$ & 139699 & 1188.4 \\
LOD & -2848.1 & 4641.8 \\
LOQ & 0.9998 & 0.9996 \\
\hline
\end{tabular}

${ }^{2}$ Average of three determinations for three concentrations $(5,10$ and $15 \mu \mathrm{g}$ $\mathrm{mL}^{-1}$ for RP-HPLC method), and (I,3 and $5 \mu \mathrm{g} / \mathrm{spot}$ for TLC-densitomrtic method) of oxfendazole repeated three times.

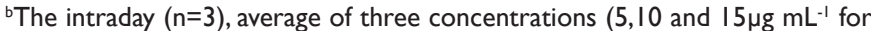
RP-HPLC method), and (I,3 and $5 \mu \mathrm{g} / \mathrm{spot}$ for TLC-densitomrtic method), of oxfendazole repeated three times within the day.

'The interday $(n=3)$, average of three concentrations $\left(5,10\right.$ and $15 \mu \mathrm{mL}^{-1}$ for RP-HPLC method), and (I,3 and $5 \mu \mathrm{g} / \mathrm{spot}$ for TLC-densitomrtic method), of oxfendazole repeated three times in three days.

Accuracy: The proposed methods were applied for measuring different concentrations of oxfendazole within their linearity range and the concentrations were calculated each from their corresponding regression equations. The accuracy of the proposed methods was calculated and RSD\% was obtained. Good results were obtained as shown in Table 1.

Precision: Precision was evaluated by calculating intraday (repeatability) and interday (Intermediate precision) precision after repeating measuring of the three different concentrations three times in the same day and assaying the sample in triplicate on three successive days using the proposed methods. The calculated RSD \% values were listed as shown in Table 1 indicating satisfying precision of the proposed methods.

Specificity: The specificity of the proposed methods was assured by applying them to laboratory prepared mixtures of the intact oxfendazole 
together with its degradation product. The proposed procedures were adopted for the selective determination of intact oxfendazole in presence of up to $80 \%$ of its degradation product for RP-HPLC method and up to $91.67 \%$ for TLC-densitometric method. The mean percentage recovery \pm SD $\%$ was shown in Table 2 . The validity of the proposed procedures is further assessed by applying the standard addition technique showing no interference from excipients. The results obtained were shown in Table 3. System suitability parameters were calculated for oxfendazole in RP-HPLC method and the results are shown in Table 4.

Table 2 Determination of oxfendazole in presence of its alkali- degradation product in their laboratory prepared mixtures by the proposed methods

\begin{tabular}{|c|c|c|c|c|c|}
\hline Method & Intact in $\left(\mu \mathrm{g} \mathrm{mL} \mathrm{L}^{-1}\right)$ & Degradate in $\left(\mu \mathrm{g} \mathrm{mL}^{-1}\right)$ & $\begin{array}{l}\text { Percent of } \\
\text { degradate }\end{array}$ & Intact found in $\left(\mu \mathrm{g} \mathrm{mL}^{-1}\right)$ & $\begin{array}{l}\text { Recovery \% of } \\
\text { intact }\end{array}$ \\
\hline \multirow{6}{*}{ RP-HPLC } & 12 & 3 & $20 \%$ & 12.15 & 101.28 \\
\hline & 10 & 5 & $33.33 \%$ & 10.03 & 100.32 \\
\hline & 5 & 10 & $66.67 \%$ & 5.04 & 100.88 \\
\hline & 3 & 12 & $80 \%$ & 3.05 & 101.87 \\
\hline & Mean \pm SD\% & & & & $101.09 \pm 0.655$ \\
\hline & Intact in ( $\mu \mathrm{g} / \mathrm{spot})$ & Degradate in ( $\mu g / s p o t)$ & $\begin{array}{l}\text { Percent of } \\
\text { degradate }\end{array}$ & Intact found in ( $\mu \mathrm{g} / \mathrm{spot})$ & $\begin{array}{l}\text { Recovery \% of } \\
\text { intact }\end{array}$ \\
\hline \multirow{6}{*}{$\begin{array}{l}\text { TLC- } \\
\text { densitometric }\end{array}$} & 5.5 & 0.5 & $8.33 \%$ & 5.46 & 99.27 \\
\hline & 5 & 1 & $16.67 \%$ & 4.94 & 98.77 \\
\hline & 3 & 3 & $50 \%$ & 2.96 & 98.96 \\
\hline & 1 & 5 & $83.33 \%$ & 0.99 & 99.14 \\
\hline & 0.5 & 5.5 & $91.67 \%$ & 0.49 & 98.14 \\
\hline & Mean \pm SD\% & & & & $98.95 \pm 0.424$ \\
\hline
\end{tabular}

Table 3 Application of standard addition technique to the analysis of Unifendazole ${ }^{\circledR}$ suspension by applying the proposed methods

\begin{tabular}{|c|c|c|c|c|}
\hline Method & Pharmaceutical Taken $(\mu \mathrm{g} / \mathrm{mL})$ & Pure added $\left(\mu \mathrm{g} \mathrm{mL}^{-1}\right)$ & Pure found $\left(\mu \mathrm{g} \mathrm{mL}^{-1}\right)$ & Recovery \% \\
\hline \multirow[t]{5}{*}{ RP-HPLC } & 5 & 3 & 2.99 & 99.76 \\
\hline & & 5 & 4.98 & 99.65 \\
\hline & & 7 & 7.01 & 100.13 \\
\hline & & 10 & 10.03 & 100.35 \\
\hline & Mean $\pm S D \%$ & & & $99.97 \pm 0.326$ \\
\hline \multirow[t]{5}{*}{ TLC-densitometric } & 2 & 1 & 0.98 & 98.65 \\
\hline & & 2 & 1.96 & 98.38 \\
\hline & & 3 & 2.97 & 99.19 \\
\hline & & 4 & 3.97 & 99.24 \\
\hline & \multicolumn{3}{|l|}{ Mean $\pm S D \%$} & $98.86 \pm 0.417$ \\
\hline \multicolumn{2}{|c|}{ Parameter } & Oxfendazole & \multicolumn{2}{|l|}{ Reference values ${ }^{21}$} \\
\hline \multicolumn{2}{|c|}{ Resolution (R) } & & \multicolumn{2}{|l|}{$\mathrm{R}>\mathrm{I} .5$} \\
\hline \multicolumn{2}{|c|}{ Selectivity factor $(\alpha)$} & & \multicolumn{2}{|l|}{$>1$} \\
\hline \multicolumn{2}{|c|}{ Retention time $\left(\mathbf{t}_{\mathbf{R}}\right)$} & & \\
\hline \multicolumn{2}{|c|}{ Capacity factor (K') } & & \multicolumn{2}{|l|}{$1-10$} \\
\hline \multicolumn{2}{|c|}{ Theoretical plates $(\mathbf{N})$} & & \multirow{2}{*}{\multicolumn{2}{|c|}{$\mathrm{T}=$ I for a typical symmetric peak }} \\
\hline Tailing $f_{c}$ & or $(T)$ & & & \\
\hline
\end{tabular}




\section{Statistical analysis}

In order to compare the ability of the proposed methods for the determination of oxfendazole in pharmaceutical preparation, the results obtained by applying each of the proposed methods and the reported spectrophotometric method ${ }^{(6)}$ were subjected to statistical analysis Table 5 . The calculated $t$ and $F$ values were less than the theoretical ones indicating that there were no significant differences between the proposed and the reported methods.

Table 5 Statistical comparison for the results obtained by the proposed methods and the reported method for the analysis of oxfendazole in Unifendazole ${ }^{\circledR}(22.5 \% \mathrm{w} / \mathrm{v})$ suspension.

\begin{tabular}{llll}
\hline & RP-HPLC & $\begin{array}{l}\text { TLC- } \\
\text { densitometric }\end{array}$ & $\begin{array}{l}\text { Reported } \\
\text { method }^{6}\end{array}$ \\
\hline$n^{*}$ & 5 & 5 & 5 \\
$X$ & 99.83 & 99.48 & 99.85 \\
$S D$ & 0.746 & 0.653 & 0.478 \\
$R S D \%$ & 0.747 & 0.656 & 0.479 \\
$t^{* *}$ & $0.060(2.306)$ & $1.021(2.306)$ & - \\
$\mathrm{F}^{* *}$ & $2.427(6.388)$ & $1.846(6.388)$ & \\
\hline
\end{tabular}

*No. of experiment

**The values in the parenthesis are tabulated values of $\mathrm{t}$ and $\mathrm{F}$ at $\mathrm{p}=0.05$ leve of significance

\section{Conclusion}

In this work, two chromatographic methods were developed and applied for the determination of oxfendazole in the presence of its alkali-induced degradation product. The advantage of the TLCdensitometric method is that several samples can be run simultaneously using a small quantity of the mobile phase, thus lowering the analysis time and cost per analysis, as well as providing high sensitivity and selectivity. The proposed methods were successfully applied to Unifendazole $^{\circledR}$ suspension and no interference from pharmaceutical formulation excipients was found.

\section{Acknowledgements}

I am deeply thankful to ALLAH, by the grace of whom this work was realized. I wish to express my indebtedness and gratitude to staff members Pharmaceutical Analytical Chemistry Department, Faculty of Pharmacy Al-Azhar University, Cairo, Egypt for their valuable supervision, continuous guidance, and encouragement throughout the whole work

\section{Conflict of interest}

The author declares there is no conflict of interest

\section{References}

1. Windholz M. The Merck Index: an encyclopedia of Chemicals. NJ: Drugs and biological. Merck \& co., Inc., Rahway; 1983.

2. Reynolds JEF. Martindale, The Extra Pharmacopia. London: The Royal Pharmaceutical Society; 1993.

3. United States Pharmacopoeia. 34th ed. National formulary 29. Official monographs. 2011.

4. Rajendraprasad N, Basavaiah K. Potentiometric determination of piroxicam and oxfendazole in pharmaceuticals. Current Chemistry Letters. 2016;5(1):33-46.
5. Nerenberg C, Runkel RA, Matin SB. Radioimmunoassay of oxfendazole in bovine, equine, or canine plasma or serum. $J$ pharm sci. 1978;67(11):1553-1557.

6. Rajendraprasad N, Basavaiah K. UV/Visible Spectroscopic Quantification Of Veterinary Anthelmintic Drug Oxfendazole In Pharmaceuticals. J Applied Spectro. 2016;83(3):392-397.

7. Tsina IW, Matin SB. Determination of Oxfendazole in Cow Milk by Reversed Phase HighPerformance Liquid Chromatography. J Pharm Sci. 1981;70(8):858-860.

8. Su SC, Chou HH, Chang PC, et al. Simultaneous Determination of Febantel, Fenbendazole,Oxfendazole and Oxfendazole Sulfone in Livestock by Matrix Solid Phase Dispersion ExtractionTechnique and HPLC. J Food and Drug Analysis. 2004;12(3):244-253.

9. Blanchflower WJ, Cannavan A, Kennedy DG. Determination of fenbendazole and oxfendazole in liver and muscle using liquid chromatography mass spectrometry. Analyst. 1194;119(6):1325-1328.

10. Shah G, Bradley D, Shek E. Liquid chromatographic determination of oxfendazole in swine feeds. J Assoc Off Anal Chem. 1984;67(4):707-714.

11. Fleitman J, Neu D, Benjamin E. Analysis of pharmaceutical dosage forms for oxfendazole: II. Simultaneous liquid chromatographic determination of oxfendazole and trichlorfon in equine paste. J Assoc Off Anal Chem. 1986;69(1):24-28.

12. Khan AR, Akhtar MJ, Mahmood R, et al. LC assay method for oxfendazole and oxyclozanide in pharmaceutical preparation. Journal of Pharm and Biomedical Anal. 2000;22(1):111-114.

13. Kulik A, Bialecka W, Podolska M, et al. HPLC Method For Identification And Quantification Of Benzimidazole Derivatives In Antiparasitic Drugs. Acta Pol Pharm. 2011;68(6):823-829.

14. Tai SS, Cargile N, Barnes CJ. Determination of thiabendazole, 5 hydroxy thiabendazole, fenbendazole, and oxfendazole in milk. J Assoc Off Anal Chem. 1990;73(3):368-373.

15. Havlíková L, Brabcová I, Satinsky D, et al. Optimisation of an HPLC method for the simultaneous determination of pyrantel pamoate, praziquantel, fenbendazole, oxfendazole and butylhydroxyanisole using a phenyl stationary phase. Anal methods. 2012;4(6):1592-1597.

16. Nakos DS, Botsoglou NA, Psomas IE. Ion- Pair Isolation and Liquid Chromatographic Dmineteration of Albendazole, Oxfendazole, Oxibendazole, and Thiabendazole Residues in Milk. $J$ Liquid Chromatography. 1994;17(19):4145-4155.

17. Klausz G, Keller E, Sára Z, et al. Simultaneous determination of praziquantel, pyrantel embonate, febantel and its active metabolites, oxfendazole and fenbendazole, in dog plasma by liquid chromatography / mass spectrometry. Biomed Chromatogr. 2015;29(12):1859-1865.

18. Malviya R, Bansal V, Pal OP, et al. High performance liquid chromatography: a short review. J Global Pharm Technol. 2010;(5):2226.

19. Renger B, editors. In Proceedings of the sixth international symposium on Instrumental planner chromatography. Bad Duerkheim, Germany; 1991.

20. Validation of Analytical Procedures, Proceedings of International Conference on Harmonization, World Health Organization. Geneva, Swizerland. 2015.

21. Adamovics JA. Chromatographic Analysis of Pharmaceuticals. New York. 1997. 